\title{
Morphological Characterization of Selected Rice (Oryza sativa L.) from Core Germplasm Group of Chhattisgarh Using DUS Descriptors
}

\author{
Suman Rawte* and Ritu R. Saxena \\ Department of Genetics and Plant Breeding, College of Agriculture, IGKV, Raipur (CG), India \\ *Corresponding author
}

\section{A B S T R A C T}

A hundred landraces of rice (Oryza sativa L.), from core group genotypes collected from

\section{Keywords}

Rice, Morphological, DUS, Germplasm

Article Info

Accepted:

04 September 2018

Available Online:

10 October 2018 different parts of Chhattisgarh, were characterized following the guidelines from the Protection of Plant Varieties and Farmers' Rights Authority, GOI. Hundred rice accessions were planted in a randomized block design (RBD). The data were recorded on 30 different agro-morphological traits (19 qualitative and 11 quantitative). The rice germplasm exhibited sufficient genetic variation for most of the qualitative and quantitative traits. Variation was observed for all the qualitative traits except the presence of collar, auricles, and ligule. The descriptors offering the most discrimination were time to $50 \%$ heading, time to maturity days, thousand grain weight, stem length, grain length, and width. Out of 30 descriptors studied, five characteristics were found monomorphic rest of the characters show variations among the accessions. The genetic potential of the mentioned accessions for the desired traits can be utilized in future rice breeding programs to get promising results.

\section{Introduction}

Rice (Oryza sativa L.) is the cereal foodstuff which forms an important part of more than three billion people's diet around the world (Shrivastava et al., 2014).

The potentially yielding ability of currently available rice varieties has to be increased twice by 2020 to meet the existing demand through utilizing valuable yield genes and genes containing resistance to biotic and abiotic stress (Fisher et al., 2012). As a staple cereal crop, rice feeds more than $50 \%$ of the world's population (Mather et al., 2007) and is one of the most important components of the human diet in many regions of the world. Rice genotypes have a greater genetic diversity than elite cultivars (or commercial cultivars) and represent an intermediate stage in domestication between wild rice and elite cultivars (Londo et al., 2006), which make it easier to be used in rice breeding than wild rice and at the same time still keeping most of the diversity in rice germplasm resource.

Therefore, mining elite genes within the germplasm of rice landraces is of importance for the improvement of cultivated rice. The landraces are valuable as they possess a huge treasure of genetic material which may prove important in future variety development 
programs, Hence, assessment of genetic diversity is very important in rice breeding from the standpoint of selection and conservation of different landraces for further utilization in crop improvement programs (Patra, 2000).

The Government of India enacted a legislation on the "Protection of Plant Varieties and Farmers Act" (PPV\&FRA) in 2001 for providing protection to plant varieties based on distinctiveness, uniformity, and stability (DUS) test apart from novelty. This is a unique and model act which gives equal importance to the farmers and breeders and treats them as partners in their efforts for sustainable food security (Patra, 2000). The concept of DUS is thus, fundamental to the characterization of a variety as a unique creation. Registration is allowed for three types of plant varieties that is new varieties bred by breeders, extant varieties and farmer's varieties subject to their fulfilling the conditions of Distinctness, Uniformity and Stability and Novelty in case of breeder's variety.

The uniqueness of a particular variety is to be established by the test called DUS. Almost in all major crop species, morphological and physiological descriptors are available to establish the uniqueness of a variety (Moukoumbi et al., 2011).

Hence, characterization and identification of rice cultivars are crucial for the genetic improvement, release, and seed production programs. Thus, characterization of these varieties will further contribute towards creating a genetic database for breeding programs strategies in the region.

\section{Materials and Methods}

The current research study was conducted at Research cum Instructional farm, College of
Agriculture, Indira Gandhi Agricultural University, Raipur, Chhattisgarh during Kharif, 2017. Hundred rice accessions were characterized using 30 different agromorphological traits (19 qualitative and 11 quantitative) based on DUS. Rice germplasm accessions used in this study are listed in the table 1. Seeding was done in the well-prepared seedbeds in the last week of June, 2017.

The seedlings were transplanted into wellpuddled field twenty-one days after seeding. Each accession was planted in two rows, with a row length of one meter and row-row distance of $25 \mathrm{~cm}$ using randomized block design (RBD) with two replications. Measurements of different morphological characteristics of these collected landraces at different stages of growth were recorded following the guidelines of test for Distinctness, Uniformity, and Stability of Rice (Oryza sativa L.) (Anonymous, 2007).

The data were collected on five randomly selected plants from each accession. Recommended cultural practices were used for growing rice crop throughout the experiment. The details of the characters and their observed genotypic descriptors are given in table 2 .

\section{Results and Discussion}

For detailed characterization or to establish distinctiveness among 100 rice landraces, 30 characters have been studied, which includes nineteen qualitative characters and eleven quantitative characters.

For the morphological characterization or identification of landraces of rice, qualitative characters are considered as morphological markers, because they are less influenced by environmental changes (Rao et al., 2013 and Kalyan et al., 2017). The rice landraces under study showed a wide range of distinctiveness 
for all most all the morphological traits studied and similar results have been reported by Joshi et al., (2007); Chakrabarty et al., (2012); Tirkey et al., (2013). Frequency distribution for all the characters under study was computed (Table 2). Qualitative and quantitative characters of different agronomic and morphological parameters are given in table 2 .

Rice genotypes were characterized for leaf traits at late vegetative and flowering stages and variation was observed among the accessions for coleoptiles color, $30 \%$ showed purple color and rest of the $70 \%$ accessions showed a green color. Similarly for basal leaf sheath color $10 \%$ accession showed purple lines, $12 \%$ showed light purple, $6 \%$ accessions showed uniform purple, while $72 \%$ accessions were showed a green color.

Character leaf intensity of green color $64 \%$ accessions had medium green color, $30 \%$ had dark green color, while $6 \%$ of the accessions showed light intensity, Leaf: Anthocyanin coloration was present in only 34 accessions, while in rest $66 \%$ does not have anthocyanin coloration in leaf.

Only 5\% accessions showed the presence of anthocyanin coloration in leaf sheath, while 95\% accessions do not have this character. Similarly, on Pubescence of blade surface of the leaf, only $8 \%$ had a hard surface, $54 \%$ showed strong, 3\% showed weak and 35\% accessions showed medium surface of the leaf blade.

Out of 100 landraces evaluated, all landraces exhibited the presence of leaf auricle, Out of which, $12 \%$ genotypes exhibited purple auricles, $9 \%$ accessions exhibited light purple auricles. There was no variation found for the trait presence of collar in the studied rice accessions. All the accessions showed the presence of collar. Out of which, 22\% accessions had the presence of anthocyanin color of the collar, while $78 \%$ of accessions does not exhibit any coloration on the collar.

For the character leaf ligule, all the landraces recorded for its presence with the split shape of ligule and having 78\%,16\% and 6\%, white, light purple and purple ligule respectively, Rawte et al., (2017) in their study had also reported $95 \%$ of landraces with split shape of ligule.

Culm attitude is an indicator of the growth habit of a particular species. During the current study valuable variation was observed among the accessions for culm angle. 1\% accessions were found to have spreading, $90 \%$ accessions shows semi-erect attitude, 8\% accessions showed open culm angle, whereas $1 \%$ accessions were having erect culm angle. For the character flag leaf attitude of the blade, semi-erect type of flag leaf was observed for $41 \%$ landraces and 59\% landraces are of an erect type. For the character density of pubescence of lemma $44 \%$ accessions were fallen in the medium category, $32 \%$ fall in weak, $23 \%$ were strong and only one genotype had a very strong density of pubescence of lemma.

All the hundred accessions were male fertile and only $40 \%$ of accessions had awns, while rest of $60 \%$ does not have awns. For the character leaf senescence, $7 \%$ were of late, $39 \%$ were of medium and $54 \%$ were of an early type. For the character's leaf length, $4 \%$ landraces exhibited medium leaf type, 96\% landraces were of a long type and for the leaf width, 19\% landraces recorded narrow type of leaves and $81 \%$ accessions recorded medium type of leaves. At an early stage the attitude of the blade of flag leaf only $1 \%$ was very short, $4 \%$ were short, $35 \%$ accessions were medium, $41 \%$ accessions were long and $11 \%$ of accessions were found to have very long flag leaf. 
Table.1 List of hundred rice genotypes for DUS based characterization

\begin{tabular}{|c|c|c|c|c|c|c|c|}
\hline $\begin{array}{l}\text { S. } \\
\text { No. }\end{array}$ & Name & $\begin{array}{l}\text { S. } \\
\text { No. }\end{array}$ & Name & $\begin{array}{l}\text { S. } \\
\text { No. }\end{array}$ & Name & $\begin{array}{l}\text { S. } \\
\text { No. }\end{array}$ & Name \\
\hline 1 & Bagri & 26 & Kanak & 51 & Ama jhopa & 76 & Ram Jira \\
\hline 2 & Hardi chudi & 27 & Mehapal & 52 & Koudi dhull & 77 & Bhejari \\
\hline 3 & Koto & 28 & $\begin{array}{l}\text { Tebaroo } \\
\text { Mundaria }\end{array}$ & 53 & Sau pankhi & 78 & Danwar \\
\hline 4 & Kotte (II) & 29 & Padari dhan IV & 54 & Dokra Dokri & 79 & Karhani \\
\hline 5 & Satha dhan & 30 & Budhiya wako & 55 & Parmal & 80 & Chiko \\
\hline 6 & Karhani & 31 & BD kankari bija & 56 & Dokrae mechha & 81 & Farsa Phool \\
\hline 7 & Kohaka & 32 & Bawati chudi & 57 & Roti & 82 & Baila Aankhi \\
\hline 8 & Luchai(A) & 33 & Kalajira & 58 & Khatia pati & 83 & Bokra Mundi \\
\hline 9 & $\begin{array}{l}\text { Angur } \\
\text { Guchcha }\end{array}$ & 34 & Sonapan & 59 & Hathi panjra & 84 & $\begin{array}{l}\text { Hunuman } \\
\text { Langur }\end{array}$ \\
\hline 10 & Basigal(ii) & 35 & Bakal & 60 & CR-1014 & 85 & Jal Ponga \\
\hline 11 & Bhejari & 36 & Cross 116 & 61 & Elayachi & 86 & Banda \\
\hline 12 & Bhulau & 37 & Deshi lal dhan & 62 & Tulsi manjari & 87 & Lanji \\
\hline 13 & Bodi & 38 & IR 42253 & 63 & Shyam jira-1 & 88 & Raja Bangla \\
\hline 14 & $\begin{array}{l}\text { Peelee } \\
\text { Luchai }\end{array}$ & 39 & Lalmati & 64 & Lokti Machhi & 89 & $\begin{array}{l}\text { Bhainsa } \\
\text { Mundariya }\end{array}$ \\
\hline 15 & Tulsi Phool & 40 & Laloo-14 & 65 & Muni Bhog & 90 & Nariyal Chudi \\
\hline 16 & Silipat & 41 & Jhitpiti & 66 & Jou Phool & 91 & Kating \\
\hline 17 & Unknown & 42 & WR99 & 67 & $\begin{array}{l}\text { Bhainsa } \\
\text { Punchhi }\end{array}$ & 92 & Bhamasur \\
\hline 18 & Ama Dhul & 43 & E-1702 & 68 & Bhanta Phool-1 & 93 & Paltu \\
\hline 19 & Baisur & 44 & Chapti gurmatia & 69 & Lahsun Bhog & 94 & Sindur senga \\
\hline 20 & Bylao & 45 & Elayachi & 70 & Ichchawati & 95 & Swarna \\
\hline 21 & Asam Chudi & 46 & Bisni-I & 71 & Laxmi Bhog & 96 & MTU-1010 \\
\hline 22 & Bhaniya & 47 & Moroberekan & 72 & Tulsi Mala & 97 & IR64 \\
\hline 23 & Farsa Phool & 48 & Nagina-22 & 73 & Jou Phool-2 & 98 & R-RF-75 \\
\hline 24 & Jalle & 49 & R-RF-75 & 74 & Jeera Phool & 99 & IGKV R1 \\
\hline 25 & Kanak Jira & 50 & Kadam Phool & 75 & Tulsi Mongra & 100 & Danteshwari \\
\hline
\end{tabular}


Table.2 Frequency distribution of landraces of rice for various DUS characters

\begin{tabular}{|c|c|c|c|c|c|}
\hline $\begin{array}{l}\text { S. } \\
\text { No. }\end{array}$ & Characteristics & States & Scale & Number of genotypes & $\begin{array}{c}\text { Frequency Distribution } \\
(\%)\end{array}$ \\
\hline \multirow[t]{3}{*}{1} & \multirow{3}{*}{ Coleoptile: Colour } & Colourless & 1 & 0 & 0 \\
\hline & & Green & 2 & 70 & 70 \\
\hline & & Purple & 3 & 30 & 30 \\
\hline \multirow[t]{4}{*}{2} & \multirow[t]{4}{*}{ Basal leaf: Sheath color } & Green & 1 & 72 & 72 \\
\hline & & Light purple & 2 & 12 & 12 \\
\hline & & Purple lines & 3 & 10 & 10 \\
\hline & & Uniform purple & 4 & 6 & 6 \\
\hline \multirow[t]{3}{*}{3} & \multirow{3}{*}{$\begin{array}{l}\text { Leaf: Intensity of green } \\
\text { color }\end{array}$} & Light & 3 & 6 & 6 \\
\hline & & Medium & 5 & 64 & 64 \\
\hline & & Dark & 7 & 30 & 30 \\
\hline \multirow[t]{2}{*}{4} & \multirow{2}{*}{$\begin{array}{l}\text { Leaf: Anthocyanin } \\
\text { coloration }\end{array}$} & Absent & 1 & 66 & 66 \\
\hline & & Present & 9 & 34 & 34 \\
\hline \multirow[t]{2}{*}{5} & \multirow{2}{*}{$\begin{array}{l}\text { Leaf Sheath: anthocyanin } \\
\text { coloration }\end{array}$} & Absent & 1 & 95 & 95 \\
\hline & & Present & 9 & 5 & 5 \\
\hline \multirow[t]{5}{*}{6} & \multirow{5}{*}{$\begin{array}{l}\text { Leaf: Pubescence of blade } \\
\text { surface }\end{array}$} & Absent & 1 & 0 & 0 \\
\hline & & Weak & 3 & 3 & 3 \\
\hline & & Medium & 5 & 35 & 35 \\
\hline & & Strong & 7 & 54 & 54 \\
\hline & & Very strong & 9 & 8 & 8 \\
\hline \multirow[t]{2}{*}{7} & \multirow[t]{2}{*}{ Leaf: Auricles } & Absent & 1 & 0 & 0 \\
\hline & & Present & 9 & 100 & 100 \\
\hline \multirow[t]{3}{*}{8} & \multirow{3}{*}{$\begin{array}{l}\text { Leaf: Anthocyanin } \\
\text { coloration of auricles }\end{array}$} & Colourless & 1 & 79 & 79 \\
\hline & & Light purple & 2 & 9 & 9 \\
\hline & & Purple & 3 & 12 & 12 \\
\hline \multirow[t]{2}{*}{9} & \multirow[t]{2}{*}{ Leaf: Collar } & Absent & 1 & 0 & 0 \\
\hline & & Present & 9 & 100 & 100 \\
\hline \multirow[t]{2}{*}{10} & \multirow{2}{*}{$\begin{array}{l}\text { Leaf: Anthocyanin } \\
\text { coloration of the collar }\end{array}$} & Absent & 1 & 78 & 78 \\
\hline & & Present & 9 & 22 & 22 \\
\hline \multirow[t]{2}{*}{11} & Leaf: Ligule & Absent & 1 & 0 & 0 \\
\hline & & Present & 9 & 100 & 100 \\
\hline 12 & Leaf: Shape of ligule & Truncate & 1 & 0 & 0 \\
\hline & & Acute & 2 & 0 & 0 \\
\hline & & Split & 3 & 100 & 100 \\
\hline 13 & Leaf: Colour of ligule & White & 1 & 78 & 78 \\
\hline & & Light purple & 2 & 16 & 16 \\
\hline & & Purple & 3 & 6 & 6 \\
\hline 14 & Culm: attitude & Erect & 1 & 1 & 1 \\
\hline & & Semi-erect & 3 & 90 & 90 \\
\hline & & Open & 5 & 8 & 8 \\
\hline & & Spreading & 7 & 1 & 1 \\
\hline 15 & Flag leaf: Attitude of blade & Erect & 1 & 59 & 59 \\
\hline & (early observation) & Semi-erect & 3 & 41 & 41 \\
\hline & & Horizontal & 5 & 0 & 0 \\
\hline & & Drooping & 7 & 0 & 0 \\
\hline 16 & Spikelet: Density of & Absent & 1 & 0 & 0 \\
\hline & pubescence of lemma & Weak & 3 & 32 & 32 \\
\hline & & Medium & 5 & 44 & 44 \\
\hline & & Strong & 7 & 23 & 23 \\
\hline & & Very strong & 9 & 1 & 1 \\
\hline
\end{tabular}




\begin{tabular}{|c|c|c|c|c|c|}
\hline \multirow[t]{2}{*}{17} & \multirow[t]{2}{*}{ Male sterility } & Absent & 1 & 100 & 100 \\
\hline & & Present & 9 & 0 & 0 \\
\hline \multirow[t]{2}{*}{18} & \multirow[t]{2}{*}{ Panicle: Awns } & Absent & 1 & 60 & 60 \\
\hline & & Present & 9 & 40 & 40 \\
\hline \multirow[t]{3}{*}{19} & \multirow[t]{3}{*}{ Leaf: Senescence } & Early & 3 & 54 & 54 \\
\hline & & Medium & 5 & 39 & 39 \\
\hline & & Late & 7 & 7 & 7 \\
\hline \multirow[t]{3}{*}{20} & \multirow[t]{3}{*}{ Leaf: Length of blade } & Short $(<30 \mathrm{~cm})$ & 3 & 0 & 0 \\
\hline & & Medium $(30-45 \mathrm{~cm})$ & 5 & 4 & 4 \\
\hline & & Long $(>45 \mathrm{~cm})$ & 7 & 96 & 96 \\
\hline \multirow[t]{3}{*}{21} & \multirow[t]{3}{*}{ Leaf: Width of blade } & Narrow $(<1 \mathrm{~cm})$ & 3 & 19 & 19 \\
\hline & & Medium $(1-2 \mathrm{~cm})$ & 5 & 81 & 81 \\
\hline & & Broad $(>2 \mathrm{~cm})$ & 7 & 0 & 0 \\
\hline \multirow[t]{3}{*}{22} & \multirow[t]{3}{*}{ Stem: Thickness } & Thin $(<0.40 \mathrm{~cm})$ & 3 & 0 & 0 \\
\hline & & Medium $(0.40-0.55 \mathrm{~cm})$ & 5 & 10 & 10 \\
\hline & & Thick $(>0.55 \mathrm{~cm}$ & 7 & 90 & 90 \\
\hline \multirow[t]{5}{*}{23} & \multirow{5}{*}{$\begin{array}{l}\text { Stem: Length (excluding } \\
\text { panicle) }\end{array}$} & Very short $(<91 \mathrm{~cm})$ & 1 & 15 & 15 \\
\hline & & Short $(91-110 \mathrm{~cm})$ & 3 & 14 & 14 \\
\hline & & Medium $(111-130 \mathrm{~cm})$ & 5 & 37 & 37 \\
\hline & & Long $(131-150 \mathrm{~cm})$ & 7 & 23 & 23 \\
\hline & & Very long $(>150 \mathrm{~cm})$ & 9 & 11 & 11 \\
\hline \multirow[t]{5}{*}{24} & \multirow{5}{*}{$\begin{array}{l}\text { Panicle: Length of main } \\
\text { axis }\end{array}$} & Very short $(<16 \mathrm{~cm})$ & 1 & 1 & 1 \\
\hline & & Short $(16-20 \mathrm{~cm})$ & 3 & 4 & 4 \\
\hline & & Medium $(21-25 \mathrm{~cm})$ & 5 & 35 & 35 \\
\hline & & Long $(26-30 \mathrm{~cm})$ & 7 & 41 & 41 \\
\hline & & Very long $(>30 \mathrm{~cm})$ & 9 & 19 & 19 \\
\hline \multirow{3}{*}{25} & \multirow{3}{*}{ Panicle: Number per plant } & Few $(<11)$ & 3 & 95 & 95 \\
\hline & & Medium (11-20) & 5 & 5 & 5 \\
\hline & & Many (>20) & 7 & 0 & 0 \\
\hline \multirow[t]{5}{*}{26} & Time of heading ( $50 \%$ of & Very early (<71 days) & 1 & 1 & 1 \\
\hline & plants with panicles) & Early (71-90 days) & 3 & 21 & 21 \\
\hline & & Medium (91-110 days) & 5 & 67 & 67 \\
\hline & & Late (111-130 days) & 7 & 11 & 11 \\
\hline & & Very late (> 131 days) & 9 & 0 & 0 \\
\hline 27 & Time maturity (days) & Very early $(<100)$ & 1 & 1 & 1 \\
\hline & & Early (101-120) & 3 & 21 & 21 \\
\hline & & Medium (121-140) & 5 & 67 & 67 \\
\hline & & Late $(141-160)$ & 7 & 11 & 11 \\
\hline & & Very late $(>160)$ & 9 & 0 & 0 \\
\hline 28 & Grain: Weight of 1000 & Very low $(<15 \mathrm{~g})$ & 1 & 22 & 22 \\
\hline & fully developed grains & Low $(15-20 \mathrm{~g})$ & 3 & 16 & 16 \\
\hline & & Medium (21-25 g) & 5 & 28 & 28 \\
\hline & & High (26-30) & 7 & 18 & 18 \\
\hline & & Very high $(>30 \mathrm{~g})$ & 9 & 16 & 16 \\
\hline 29 & Grain: Length & Very short $(<6.0 \mathrm{~mm})$ & 1 & 10 & 10 \\
\hline & & Short (6.1-8.5 mm) & 3 & 46 & 46 \\
\hline & & Medium (8.6-10.5 mm) & 5 & 32 & 32 \\
\hline & & Long $(10.6-12.5 \mathrm{~mm})$ & 7 & 10 & 10 \\
\hline & & Very long $(>12.5 \mathrm{~mm})$ & 9 & 2 & 2 \\
\hline 30 & Grain: Width & Very narrow $(<2.0 \mathrm{~mm})$ & 1 & 5 & 5 \\
\hline & & Narrow $(2.1-2.5 \mathrm{~mm})$ & 3 & 33 & 33 \\
\hline & & Medium $(2.6-3.0 \mathrm{~mm})$ & 5 & 34 & 34 \\
\hline & & Broad (3.1-3.5 mm) & 7 & 26 & 26 \\
\hline & & Very broad $(>3.5 \mathrm{~mm})$ & 9 & 2 & 2 \\
\hline
\end{tabular}


With respect to the stem characters, for the stem length (excluding panicle) $15 \%$ landraces were of very short, $14 \%$ were of short, $37 \%$ were of the medium type, $23 \%$ and $11 \%$ were of long and very long type respectively. With respect to the thickness of stem, $10 \%$ were of medium and $90 \%$ were of thick. $95 \%$ of accessions had a few numbers of panicles plant ${ }^{-1}$ and $5 \%$ accessions fall under the medium category. Coming to the time of heading (50\% of plants with panicles) were observed and noticed that $11 \%$ landraces were of late-type (111-130 days) and 1\% landraces were of very early ( $<71$ days) duration types, $21 \%$ landraces were of earlytype (71-90 days) and 67\% landraces were of medium (91-110 days) duration. For the character time of maturity (days), 1\% landraces were of very early ( $<100$ days), $21 \%$ landraces were of early (101-120 days), $67 \%$ landraces were of medium (121-140 days) and $11 \%$ landraces were of late (141160 days) duration types. Bose and Pradhan (2005) also reported high genetic divergence in days to $50 \%$ flowering.

For the character grain weight of 1000 fully developed grains, Highest number of the genotypes $(22 \%)$ showed very low grain weight ( $<15 \mathrm{~g})$, followed by $18 \%$ genotypes with high (26-30 g) and medium (21-25 g) grain weight, $16 \%$ genotypes showed very high (> $31 \mathrm{~g})$ as well as low (15-20 g) grain weight. Thousand grain weights have been used for characterizing rice varieties by several researchers; Joshi et al., (2007) noticed the variability for most of the morphological traits signified their utility in varietal characterization in 19 varieties of rice. For the character grain length, 46\% accessions were found under short category followed by $32 \%$ medium, $10 \%$ under very short and long category and about $2 \%$ of accessions were having very long grain length. With the character grain width 34\% accessions fall under medium, 33\% under narrow, 26\% under broad, 5\% very narrow and $2 \%$ accessions found under the very broad category.

Morphological markers are very important and all breeders are continuously looking for these markers that will enable them to identify specific parental material for specific traits. The present study revealed sufficient genetic variability for various qualitative and quantitative traits. Thus, the various analysis carried out had shown wide variability among the 100 genotypes for the 30 traits. The wide range of variability observed for the characters evaluated may be attributed to the diverse genetic background of the accessions studied and these could be used for selection of the genotypes for crosses.

\section{References}

Anonymous, 2007, Guidelines for the Conduct of Test for Distinctiveness, Uniformity and Stability on Rice (Oryza sativa L.) PPV \& FR Authority, GOI, New Delhi, pp. 5-12.

Bose, L.K and S.K. Pradhan, 2005. Genetic divergence in deep water rice genotypes. Journal of Control, European Agriculture. 6 (4): 635-640.

Chakrabarty, S.K., M.A., Joshi, Y., Singh, A., Maity, V. Vashisht, and M. Dadlani, 2012. Characterization and evaluation of variability in farmers' varieties of rice from West Bengal. Ind. J Gen.; 72: 136-142.

Fischer, K.S., S., Fukai, A., Kumar, H. Leung, and B. Jongdee, 2012. Field phenotyping strategies and breeding for adaptation of rice to drought. Frontiers Physiol. 3: 282.

Joshi, M.A., N.K., Sarao, R.C., Sharma, P. Singh, and T.S. Bharaj, 2007. Varietal characterization of rice (Oryza sativa L.) based on morphological descriptors. Seed Res. 35:188-193. 
Kalyan, B., K.V.R., Krishna, S.L.V. Rao, 2017. DUS Characterization for Germplasm of Rice. Int. J. Curr. Microbiol. App. Sci. 6:3480-3487.

Londo, J.P., Y.C., Chiang, K.H., Hung, T.Y. Chiang, and B.A. Schaal, 2006. Phylogeography of Asian wild rice, Oryza rufipogon, reveals multiple independent domestications of cultivated rice, Oryza sativa. Proc Natl Acad Sci U S A 103: 9578-9583.

Mather, K.A., A.L., Caicedo, N.R., Polato, K.M. Olsen, and S. Mc Couch 2007. The extent of linkage disequilibrium in rice (Oryza sativa L.). Genetics 177: $2223-2232$.

Moukoumbi, Y.D., M., Sie, R., Vodouhe, B., Ndri, B., Toulou, S.A. Ogunbayo, and A. Ahanchede, 2011. Assessing phenotypic diversity of interspecific rice varieties using agro-morphological characterization. J Plant Breed Crop Sci. 3(5): 74-86.

Patra, B.C. 2000. Collection and characterization of rice genetic resources from Keonjhar district of Orissa. Oryza. 34:324-326.

Rao, S.L.V., G.S., Prasad, M., Chiranjivi, U. Chaitanya, and R. Surendhar, 2013. DUS Characterization for Farmer varieties of rice. IOSR J. Agric. Vet. Sci. 4:35-43.

Rawte, S., R.R., Saxena, H. Sahu, and S.B. Verulkar, 2017. Study of Agromorphological Variation of Rice (Oryza sativa L.) Germplasm Collected from Different Parts of Chhattisgarh. Trend. in Biosci. 10(11):2078-2086.

Srivastava, N., S.K. Pathak, S. Gampala, V.J. Singh, B.G. Suresh and G.R. Lavanya. 2014. Evaluation of exotic upland rice germplasm for grain yield and its component characters in rainfed ecosystem (Oryza sativa L). Int. J. Food Agri. and Vet. Sci., 4(2): 102-109.

Tirkey, A., A.K., Sarawgi, Rao and S.L. Verma. 2013. Studies on genetic diversity in various qualitative and quantitative characters in rice germplasm. Ind. J Plant. Gen. Res. 26:132-137.

\section{How to cite this article:}

Suman Rawte and Ritu R. Saxena. 2018. Morphological Characterization of Selected Rice (Oryza sativa L.) from Core Germplasm Group of Chhattisgarh Using DUS Descriptors. Int.J.Curr.Microbiol.App.Sci. 7(10): 350-357. doi: https://doi.org/10.20546/ijcmas.2018.710.037 